\title{
Human Exposure Assessment of Element Pollution for Environmental Health Implications: Teeth as a Biomonitoring Tool
}

\author{
Athimoolam Sukumar \\ Department of Education in Science and Mathematics, Regional Institute of Education (RIE), National Council of Educational \\ Research and Training (NCERT), Mysore, India \\ Email: sukumarindia@rediffmail.com
}

How to cite this paper: Sukumar, A. (2018) Human Exposure Assessment of Element Pollution for Environmental Health Implications: Teeth as a Biomonitoring Tool. Journal of Geoscience and Environment Protection, 6, 37-53. https://doi.org/10.4236/gep.2018.63005

Received: January 31, 2018

Accepted: March 10, 2018

Published: March 13, 2018

\begin{abstract}
Reference values reflecting the findings of natural concentrations of teeth in a well-defined group of individuals, are indispensable, if one is to interpret results generated for clinical utility. Hence, a comprehensive compilation of literature survey is attempted to make available as a reference guideline for tooth element concentrations. Presently, the reference values are proposed for 19 elements. Several factors that are found influencing element levels, are common to any biosample and are broadly grouped under four categories namely, the factors of teeth, donor, environment and analytical methods. How best the influencing factors to be considered during analysis, are discussed. It is elucidated that standardized method of analysis with quality assurance and precision will reduce the ambiguity of comparison of inter-laboratory measurement. When the merits and demerits of element measurements are evaluated, it is recognized that except a hurdle of difficult specific sampling, many advantages make teeth an attractive material for environmental health monitoring of population and for assessment of element status of deficiency and excess due to differential exposure. The available data of tooth elements are lesser in comparison to data of blood and hair; further studies are required for reference values of others elements and for distribution pattern in different conditions, parts and types of teeth.
\end{abstract}

\section{Keywords}

Environmental Health Monitoring, Elements, Human Teeth, Reference Values, Element Exposure 


\section{Introduction}

Reference or baseline values of teeth are determined to explain adequately functions of various elements and the changes that occur in their concentrations in pathologic states and to conduct large scale epidemiologic studies. At present, human teeth are widely analyzed for levels of elements that are compared with available levels of other studies. In such cases also, the well-founded reference values are needed. A meticulous appraisal of literature values published by Iyengar et al. [1], served as a guideline for many elements and tissues, except human teeth. The purpose of present review is to identify the baseline data for the concentrations of tooth elements. Besides, a number of factors that are influencing the levels are discussed and merits and demerits of use in status assessment are evaluated for consideration of effective tooth element analysis.

\section{Reference Values}

In majority, multi-elements are analyzed in teeth because of easy analytical procedure with inter-laboratory quality assurance; in specific cases, single element e.g. lead or fluoride or other bone seeking elements are exclusively determined and their levels $(\mathrm{ppm} / \mu \mathrm{g} / \mathrm{g} \pm \mathrm{SD}$, Standard Deviation, or otherwise mentioned) are here elucidated.

\subsection{Lead}

Being one of the most important environmental pollutants, lead $(\mathrm{Pb})$ is a common choice of selection. In Table 1 are shown lead levels of deciduous and permanent teeth estimated in the subjects of several places [2]-[18]. The mean lead levels determined in deciduous teeth of children from different regions are 1.3 (Sao Paulo Brazil), 1.43 (Czech Republic), 1.47 (Poland), 1.77 (Poland), 3.1 (Venezuela), 3.42 (Turkey) and 5.78 (Karachi) and are very much lower than that of 30.26 (Jordan) and 92.4 (Charleston SC, USA). In both incisors and canines of deciduous teeth, 8.1 and 4.1 were respectively found in the children of Finland; whereas higher levels were reported in incisors (40.67), canine (46.77) and molars (39.56) of children from zinc-lead smelter areas of Rajasthan.

In permanent teeth of resident subjects, less than $10 \mu \mathrm{g} / \mathrm{g}$ level of $\mathrm{Pb}$ were reported in Kyoto (1.2), Graz, Austria (1.7 $\mu \mathrm{g} / \mathrm{g}$ ), Klina, Kosovo (3.2) and Kuwait (5.6 females and 6.8 males). Higher levels were also observed in Mitrovica (22.3), in Virginia (43.2 \pm 1.0 (enamel) and $38.9 \pm 1.4$ (dentine)).

Besides lead, other elements estimated in deciduous and permanent teeth of subjects from different places are shown in Table 2; the element-wise concentrations ( $\mathrm{ppm})$ are discussed for their status in use of reference values:

\subsection{Cadmium (Cd)}

The estimated mean concentrations of cadmium are 0.028 (non-urban children), 0.03 (urban children), 0.04 (children from Poland), 0.054 (control adult subjects) and 0.55 (children from Jordan). 
Table 1. The reported lead levels of deciduous (DT) and permanent (PT) teeth in the subjects of different places.

\begin{tabular}{|c|c|c|c|c|c|c|}
\hline$S \mathrm{~N}$ & Subjects & Place & Tooth Type & $\begin{array}{c}\text { Mean Level } \\
(\mathrm{ppm} / \mu \mathrm{g} / \mathrm{g} \pm \mathrm{SD})\end{array}$ & Method & Ref. \\
\hline 1 & Children & Sao Paulo Brazil & $\mathrm{DT}$ & 1.3 & ICP-MS & {$[2]$} \\
\hline 2 & Children & $\begin{array}{l}\text { Pribram, Czech } \\
\text { Republic }\end{array}$ & DT & 1.43 & AAS & {$[3]$} \\
\hline 3 & Children & $\begin{array}{c}\text { suburban areas of } \\
\text { Turkey }\end{array}$ & DT & $1.30-1.77$ & AAS & {$[4]$} \\
\hline 4 & $\begin{array}{l}\text { Children }(5-7 \mathrm{yr}) \\
\text { from Poland }\end{array}$ & $\begin{array}{l}\text { Non-urban } \\
\text { Urban }\end{array}$ & DT & $\begin{array}{l}1.77 \pm 1.79 \\
1.47 \pm 1.7\end{array}$ & AAS & {$[5]$} \\
\hline 5 & $\begin{array}{l}\text { Male \& Female } \\
\text { children }\end{array}$ & Merida, Venezuela & Healthy DT & $3.10 \pm 0.97$ & AAS & {$[6]$} \\
\hline 6 & Children & $\begin{array}{c}\text { Urban \& } \\
\text { suburban Ankara }\end{array}$ & DT & 3.42 & AAS & [7] \\
\hline 7 & Children & Karachi & DT & 5.78 & AAS & {$[8]$} \\
\hline 8 & Children of 5 to $12 \mathrm{yr}$ & Jordan & DT & 30.26 & ICP & [9] \\
\hline 9 & $\begin{array}{l}\text { Preadolescent Negro } \\
\text { children }\end{array}$ & Charleston SC, USA & DT & $92.4 \pm 41.9$ & AAS & [10] \\
\hline 10 & $\begin{array}{l}\text { 6-yr-old children } \\
\text { 9-yr-old children }\end{array}$ & Finland & $\begin{array}{l}\text { DT incisors } \\
\text { DTcanines }\end{array}$ & $\begin{array}{l}8.1 \pm 5.3 \\
4.1 \pm 2.6\end{array}$ & PIXE & [11] \\
\hline 11 & Children & $\begin{array}{l}\text { zinc-lead smelter } \\
\text { area of Dariba, India }\end{array}$ & $\begin{array}{c}\text { Incisors } \\
\text { Canine } \\
\text { Molars of DT }\end{array}$ & $\begin{array}{l}40.67 \pm 21.06 \\
46.77 \pm 50.10 \\
39.56 \pm 34.33\end{array}$ & AAS & [12] \\
\hline 12 & Women & Kyoto & PT & $1.2 \pm 0.5$ & $\mathrm{XRF} \& \mathrm{ICP}$ & [13] \\
\hline 13 & $\begin{array}{c}\text { Females } \\
\text { Males }\end{array}$ & Kuwait & PT dentin & $\begin{array}{l}5.6 \pm 4.6 \\
6.8 \pm 4.7\end{array}$ & AAS & [14] \\
\hline 14 & Residents & $\begin{array}{c}\text { Mitrovica } \\
\text { (Kosovoa) } \\
\text { Klina (Kosovoa) } \\
\text { Graz (Austria) }\end{array}$ & $\mathrm{PT}$ & $\begin{array}{l}3.2 \\
1.7\end{array}$ & ICP-MS & [15] \\
\hline 15 & $10-12$ yr old children & Virginia & $\mathrm{PT}$ & $\begin{array}{l}43.2 \pm 1.0(\mathrm{e}) \\
38.9 \pm 1.4(\mathrm{~d})\end{array}$ & NAA & [16] \\
\hline 16 & $\begin{array}{c}\text { All subjects, (children } \\
\text { \& adult) }\end{array}$ & $\begin{array}{c}\text { Hoboken } \\
\text { (industrial) } \\
\text { Brussels (urban) } \\
\text { Arlon (rural) }\end{array}$ & PT & $\begin{array}{c}35.35 \pm 6.0 \\
17.72 \pm 4.16 \\
21.45 \pm 4.35\end{array}$ & AAS & [17] \\
\hline & $\begin{array}{l}\text { Lead-poisoned } \\
\text { children }\end{array}$ & & & $601 \pm 225$ & & \\
\hline 17 & Children & Suburban Boston & DT dentine & $84.4 \pm 56.6$ & ASV & [18] \\
\hline & Healthy children & Iceland & & $35.9 \pm 29.5$ & & \\
\hline
\end{tabular}

Note: Atomic Absorption Spectrophotometry (AAS), Inductively Coupled Plasma-Mass Spectrophotometry (ICP-MS), Proton Induced X-Ray Emission Spectrophotometry (PIXE), Anodic Stripping Voltametry (ASV), X-Ray Fluorescence Spectrometry (XRF). 
Table 2. Levels of elements reported in deciduous (DT) and permanent (PT) teeth of subjects from different places.

\begin{tabular}{|c|c|c|c|c|c|c|c|}
\hline No & Subjects & Place & Tooth Type & Element & $\begin{array}{c}\text { Levels }(\mathrm{ppm}) / \\
(\mu \mathrm{g} / \mathrm{g} \pm \mathrm{SD})\end{array}$ & Method & Ref. \\
\hline 1 & $\begin{array}{l}\text { Children } 5 \text { - } 7 \text { yr } \\
\text { old }\end{array}$ & $\begin{array}{c}\text { Non-urban } \\
\text { Urban }\end{array}$ & $\mathrm{DT}$ & $\mathrm{Cd}$ & $\begin{array}{l}0.028 \pm 2.5 \\
0.03 \pm 2.63\end{array}$ & AAS & [5] \\
\hline 2 & Normal subjects & & $\mathrm{PT}$ & As & 0.060 & NAA & [22] \\
\hline 3 & Children & North Carolina & $\begin{array}{l}\text { Incisors-DT } \\
\text { molars-DT }\end{array}$ & $\mathrm{F}$ & $\begin{array}{l}792 \pm 402 \\
768 \pm 489\end{array}$ & $\begin{array}{l}\text { Ion specific } \\
\text { electrode }\end{array}$ & [19] \\
\hline 4 & Healthy Children & Southern Poland & $\mathrm{DT}$ & $\begin{array}{l}\mathrm{Mn} \\
\mathrm{Fe} \\
\mathrm{Cu} \\
\mathrm{Cr}\end{array}$ & $\begin{array}{c}4.39 \pm 3.72 \\
51.0 \pm 23.9 \\
4.62 \\
8.97 \pm 1.94\end{array}$ & AAS & {$[24]$} \\
\hline 5 & Children & $\begin{array}{l}\text { Dalmatia \& } \\
\text { Novigrad, } \\
\text { Yugoslavia }\end{array}$ & $\begin{array}{c}\text { Enamel of caries } \\
\text { free teeth }\end{array}$ & $\mathrm{V}$ & $3.7 \pm 1.5 \mathrm{ng} \cdot \mathrm{g}^{-1}$ & NAA & [25] \\
\hline 6 & Adults & Finland & PT & $\mathrm{Ni}$ & $0.9 \pm 0.7 \mathrm{pg} / \mathrm{g}$ & AAS & [21] \\
\hline 7 & $\begin{array}{c}\text { Children of } 5 \text { to } \\
12 \mathrm{yr}\end{array}$ & Jordan & DT & $\begin{array}{l}\mathrm{Cd} \\
\mathrm{Cu} \\
\mathrm{Fe} \\
\mathrm{Zn}\end{array}$ & $\begin{array}{c}0.55 \\
6.23 \\
34.72 \\
128.21\end{array}$ & ICP & [9] \\
\hline 8 & Women & Kyoto & $\begin{array}{l}\text { Enamels of } \\
\text { molar teeth } \\
\quad(\mathrm{PT})\end{array}$ & $\begin{array}{l}\mathrm{Hg} \\
\mathrm{Cu} \\
\mathrm{Zn}\end{array}$ & $\begin{array}{c}1.7 \pm 0.2 \mathrm{ng} / \mathrm{g} \\
0.9 \pm 1.1 \\
150 \pm 24.6\end{array}$ & ICP-MS & [13] \\
\hline 9 & $\begin{array}{l}\text { 6-yr-olds children } \\
\text { 9-yr-old children }\end{array}$ & Finland & $\begin{array}{l}\text { DT incisors } \\
\text { DT canines }\end{array}$ & $\begin{array}{l}\mathrm{Zn} \\
\mathrm{Sr} \\
\mathrm{Zn} \\
\mathrm{Sr}\end{array}$ & $\begin{array}{c}150 \pm 29 \\
63 \pm 18 \\
142 \pm 22 \\
85 \pm 13\end{array}$ & PIXE & [11] \\
\hline 10 & $\begin{array}{l}\text { Male and Female } \\
\text { children }\end{array}$ & Merida, Venezuela & Healthy DT & $\begin{array}{l}\mathrm{Sr} \\
\mathrm{Cu} \\
\mathrm{Zn}\end{array}$ & $\begin{array}{c}38.37 \pm 4.82 \\
1.21 \pm 0.86 \\
85.33 \pm 12.98\end{array}$ & AAS & [6] \\
\hline 11 & $\begin{array}{l}\text { Subjects from high } \\
\text { Sr areas } \\
\text { Subjects from low } \\
\text { Sr areas }\end{array}$ & $\begin{array}{l}\text { Fort Recovery } \\
\text { Delphos } \\
\text { Rochester }\end{array}$ & PT & $\mathrm{Sr}$ & $\begin{array}{l}564.0 \\
485.5 \\
\\
80.2\end{array}$ & AAS & [26] \\
\hline
\end{tabular}

\subsection{Fluoride (F)}

The average dentin fluoride concentrations per exfoliated primary tooth were $792 \pm 402$ for incisors and $768 \pm 489$ for molars of children from North Carolina [19]. Higher fluorine content was indentified in the healthy teeth (304.8) than in the teeth with decay (235.6) [20], while low levels $87.9 \pm 8.5$ (enamel) and 133.5 \pm 19.1 (dentin) were found in permanent teeth of 10 - 12 year old subjects from Virginia [14].

\subsection{Nickel (Ni), Arsenic (As) and Mercury (Hg)}

The concentration of Ni $0.9 \pm 0.7$ [21], a range of $0.031-0.145$ and a mean value 
of 0.060 of arsenic in the permanent teeth were reported [22], while the level of $\mathrm{Hg}(1.7 \pm 0.2 \mathrm{ng} / \mathrm{g})$ was found in the permanent teeth of women from Kyoto [13].

\subsection{Manganese (Mn)}

A value of 4.0 manganese measured in enamel by Little and Steadman [23], is lower than the values $(7.41 \pm 0.13$ in enamel and $6.20 \pm 0.16$ in dentin) determined with Nuclear Activation Analysis (NAA) by Derise and Ritchey [16].

\subsection{Iron $(\mathrm{Fe})$}

A range of 20.0 to 44.0 of iron in sound enamel was reported by Little and Steadman [23]. The mean iron values indentified by others were within the ranges; 34.72 was the concentration found in the deciduous teeth of children of 5 to 12 year old living in Irbid, Jordan [9]; $38.6 \pm 1.3$ in enamel and $42.1 \pm 1.7$ in dentin were measured with NAA in the permanent teeth of children from Virginia and also mean dentin (42.8) and enamel (39.5) concentrations [16]. Whereas, the values of Retief et al. [27] observed in enamel (118.0) and dentin (93.0) were the highest.

\subsection{Cobalt (Co)}

Derise and Ritchey [16] estimated Co values (32.2 \pm 0.8 , enamel and $33.0 \pm 0.8$, dentin) in the permanent teeth of the children from Virginia. These Values are much higher than the values that were observed by Retief et al. [27] for Co.

\subsection{Strontium (Sr)}

Strontium concentrations observed by others in different tooth types are $1.21 \pm$ 0.86 in healthy deciduous teeth of children from Venezuela [6], $63 \pm 18$ and $85 \pm$ 13 respectively in incisors and canines of $6 \mathrm{yr}$ old and $9 \mathrm{yr}$ old Finnish children [11], 67.0 [28], 100.7 [29], but both higher 564.0 and lower 80.2 in the whole teeth of subjects from high and low $\mathrm{Sr}$ areas were found [26]. More or less similar levels, 80.0 to 181 and 67 to 161 respectively were reported in permanent and deciduous enamel of subjects from 12 UKtown [30]. The mean Sr concentrations, 285.6 and 180.1 found by Derise and Ritchey [16] are within the range of 80 to 450 reported by Retief et al. [27]. Steadman et al. [31] determined Sr range from 80 to $620 \mathrm{ppm}$ in teeth from different geographic areas. The higher amount of enamel strontium were reflected due to strontium available from the water supplies, and presumably also in the food.

\subsection{Selenium (Se)}

The values $0.47 \pm 0.04$ and $0.25 \pm 0.03$ were determined respectively in enamel and dentin of permanent teeth of Virginia children [16], while similar concentrations of selenium were determined in enamel and dentine from 0.43 to 1.6 [32] and in enamel (0.21 to 2.08$)$ and dentin (0.35 to 0.43$)$ [33]. 


\subsection{Copper (Cu)}

Very low copper values of 0.26 and 0.21 were found respectively in the enamel and dentin [34], in comparison to the values of $11.5 \pm 2.0$ (enamel) and $7.5 \pm 1.3$ (dentin) of the children's permanent teeth [16]. Brudevold and Steadman [35] stated a range of 12 to 30, whereas Nixon and Smith [22] reported a range of 1.6 to 30 for enamel. Whole teeth level of copper, $0.9 \pm 1.1$ was lower in the permanent teeth of women from Kyoto [13] than that of 6.23 found in the $5-12$ year children of Jordan [9] and 9.92 in the boys and girls living in the Upper Silesian Industry Region, Southern Poland [36].

\subsection{Zinc (Zn)}

The estimated Zinc levels of deciduous teeth were 128.2 in Jordan children of 5 to 12 year old [9], $150 \pm 29$ and $142 \pm 22$ respectively in the deciduous incisors of 6-yr-old and deciduous canines of 9-yr-old Finnish children [11]. Fosse and Justesen [37] suggested that teeth with zinc concentrations lower than 90.0, might represent children with marginal zinc supply. Enamel and dentine values of zinc reported were respectively $190.6 \pm 4.1$ and $148.9 \pm 8.9$ [16] and 263.0 in enamel and 173.0 in dentin [27]. A range of 58 to 200 in layered enamel samples was shown by Nixon et al. [38].

\subsection{Aluminum (Al)}

The determined $\mathrm{Al}$ values were $86.6 \pm 2.5$ in enamel and $63.4 \pm 1.5$ in dentin of permanent teeth of Virginia children with the enamel having the higher concentration [4/16]. Similar values in enamel (86.13) and dentin (68.06) [27] were identified with a range from 95 to 220 in sound enamel [8/23].

\subsection{Vanadium (V), Iodine (I), Barium (Ba), Chromium (Cr) and Calcium (Ca)}

Byrne and Vrbic [25] determined a mean vanadium concentration of $3.7 \pm 1.5$ $\mathrm{ng} / \mathrm{g}$ for 37 dental enamel samples of subjects from a low caries area of Dalmatia, Zemunik (DMFT $<2$, decayed, missing, and filled teeth index), and a normal area, Novigrad (DMFT $>5$ ); Derise and Ritchey [16] identified iodine values of $4.66 \pm 0.62$ and $4.05 \pm 0.41$ respectively in enamel and dentin of permanent teeth of children. The significantly higher level of $\mathrm{Ba}$ (10.5) was found in deciduous teeth than in the impacted teeth value of 4.3 in the population of children and adults (aged 6 - 78) living in an industrial area of Poland and chromium (8.97 \pm 11.94) and calcium of $20 \pm 11.9$ concentrations were found in the deciduous teeth of healthy children from Poland [24].

Tooth levels of 19 elements are compiled; considering their physiological roles at deficiency or excess status of essential, non-essential and toxic effects and the normal concentrations between deficiency and excess, the proposed reference values (ppm) are $10.0(\mathrm{~Pb}), 1.0 \mathrm{ng} / \mathrm{g}(\mathrm{Hg}), 0.05(\mathrm{Cd}), 0.05(\mathrm{As}), 100.0(\mathrm{~F}), 0.5$ pg/g (Ni)150.0 (Zn), $10.0(\mathrm{Cu}) 10.0(\mathrm{Ca}), 2.0(\mathrm{Cr}) 0.5(\mathrm{Se}), 150.0(\mathrm{Sr}), 2.0(\mathrm{Mn})$, $10.0(\mathrm{Co}), 2.0(\mathrm{Ba}), 2.0 \mathrm{ng} / \mathrm{g}(\mathrm{V}), 5.0(\mathrm{I}), 20.0(\mathrm{Fe})$ and $10.0(\mathrm{Al})$. 


\section{Influencing Factors}

Many factors of individual subject, teeth, environment and method of analysis are associated with levels of elements measured (Table 3 ) and hence comparison of their levels within and with different subject groups may be subjected to variations and validity.

\subsection{Personal Characters}

\subsubsection{Sex}

A statistically insignificant difference of tooth lead levels were shown between boys and girls [8] [39] between Spanish males and females [40]. Similar conclusions were reached by a study in Finland [41]. In contrast, lead [14] [42] and Mn [43] concentrations were significantly higher in males than in females. Thus, both no significance and significance in element levels were observed due to genders.

\subsubsection{Health}

Lead levels of teeth were higher in the hypertensives and diabetics, whereas copper levels were lower in the hypertensives from Mysore, India [44]. Higher lead exposure found more through higher tooth levels in the urban children of Alexandria City was associated with a degree of anaemia, lack of school interest, unexplained mental retardation or poor school performance, when blood lead levels are not too high [39].

\subsubsection{Age}

There was a significant increase in tooth lead levels with advancing age of the subjects from Coruña, Spain [40], but a few studies indicated stated that accumulation of lead in teeth was not correlated with chronological age [8] [44].

\subsubsection{Smoking and Alcohol Consumption}

The concentrations of $\mathrm{Pb}$ and $\mathrm{Cd}$ in teeth from smokers ( $\mathrm{Pd} 31.89$ and $\mathrm{Cd} 0.49$ ) were significantly higher than those from nonsmokers ( $\mathrm{Pb} 24.07$ and $\mathrm{Cd} 0.37$ ) of four Jordan cities such as, Amman, Zarqa, Al-Mafraq and Irbid [45], while no difference was observed due to smoking and alcohol consumption [44].

\subsubsection{Other Factors}

The socio-demographic factors may affect the lead level in children; certain

Table 3. Four main categories of factors influencing tooth element levels.

\begin{tabular}{|c|c|c|c|c|}
\hline \multirow{2}{*}{ SN } & \multicolumn{4}{|c|}{ Factors/characters influencing element levels in teeth } \\
\hline & Individual & Tooth & Environment & Analytical method \\
\hline & Sex & Types & Region \& place of residence & Sampling procedures \\
\hline & Age & Caries & Urban \& rural exposure & Methods of digestion \\
\hline & Diet & filling materials & Others & Instruments used \\
\hline & Smoking & Others & & Others \\
\hline & Health status & & & \\
\hline & Others & & & \\
\hline
\end{tabular}


factors viz., family income per capita per month, number of sibling and parental education, were not significantly correlated with higher tooth lead levels [39]. Other cases, the higher zinc level was found in vegetarian subjects than that of non-vegetarians subjects from Mysore, India [44].

\subsection{Tooth Factors}

\subsubsection{Types}

Sound primary and permanent enamel: The concentrations of $\mathrm{F}, \mathrm{Sr}$, and $\mathrm{K}$ were significantly $(\mathrm{P}<0.05)$ higher in sound enamel of permanent teeth than that of sound enamel of primary teeth, whereas the concentrations of $\mathrm{Al}, \mathrm{Si}$, and $\mathrm{Cu}$ were significantly $(\mathrm{P}<0.05)$ higher in sound enamel of primary teeth than the sound enamel of permanent teeth [46]. Incisor had a significantly higher mean lead levels, $6.42 \pm 4.19$ than canines $(4.91 \pm 5.12)$ and molars $(4.50 \pm 2.67)$ $[15 / 8]$.

\subsubsection{Carious and Non-Carious Teeth}

Concentrations of $\mathrm{Si}$ and $\mathrm{Cu}$ were not significant $(\mathrm{P}>0.05)$ between the sound and carious enamel of primary and permanent teeth, but concentrations of $\mathrm{F}, \mathrm{K}$, and Si were significantly $(\mathrm{P}<0.05)$ higher in sound enamel of primary teeth than that of the concentrations of carious enamel of primary teeth [46]. The $\mathrm{Cu}$ level in children with caries experience was significantly higher than that of the sound teeth group and $\mathrm{Mn}$ levels were similar with or without caries and treatment [43].

\subsubsection{Effects of Filling Material-Amalgam}

Lead (31.02) and cadmium (0.52) concentrations in teeth of Jordanian patients with amalgam fillings were significantly higher than those from patients without the fillings ( $\mathrm{Pb} 26.87$ and $\mathrm{Cd} 0.41)$ [45].

\subsubsection{Biological Characters}

Human tooth, having basically made up of two parts, the crown and the root, has a complex system of heterogeneous, specialized tissues viz., enamel, dentin, cementum and pulp. Its tissues are similar to those materials making up bone and has also contain organic matter and various trace elements distributed in varying proportions in its structure. The major inorganic components are calcium, phosphate, carbonate, magnesium and sodium. Elemental distribution can provide information about 1) physiology, 2) environmental influence, 3) dietary habits, 4) contamination by metallic amalgams used as restorative material and 5) correlation of chemical composition and local variations with mechanical characteristics of enamel.

\section{1) Enamel}

It is one of the most essential structures of tooth, both from a functional and esthetic point of view. Its mineralization is a gradual process, still continuous at 6 months post-natally in the primary mandibular incisors, while demineralization depends on the degree of mineralization and the chemical content of the 
enamel exposed. In enamel, this mineral phase is not subject to turnover, since it consists of biological mineral hydroxyapatite, where various ions may be substituted into the crystal lattice only during the development. Thus, the enamel encapsulates a permanent record of the trace element environment during the development of a tooth.

\section{2) Dentin}

Dentine is the next underlying layer of enamel. The pulpal dentine, this last being a thin layer of new dentine lining the interior of the pulp cavity and deposited slowly during the whole life of the tooth. The bulk of the pulp is similar in composition to connective tissue, containing various types of cells, collagen fibers, nerve trunks, lymphatic and blood vessels. There is no active metabolism of elements after the completion of dentin that is surrounded by enamel and cementum, and is not affected by the oral environment [47]. Therefore, the amount of trace elements in dentin may change with age, and this is considered to be a reliable biological load index.

\subsection{Environmental Factors}

\section{Living Place}

Many studies revealed higher levels of elements in the subjects from industrial areas or urban, particularly lead in the children and adult from Belgium [17], contaminated zone [10/3], Alexandria City [39] and urban Mysore city, India [44] than rural areas. But no difference in the lead level was also found between non-urban $(0.028 \pm 2.5)$ and urban $(0.03 \pm 2.3)$ preschool children from Krakow, southeastern Poland [5]. The tooth levels of $\mathrm{Cd}, \mathrm{Pb}, \mathrm{Zn}, \mathrm{Cu}, \mathrm{Cr}, \mathrm{Ni}$ and $\mathrm{Mn}$ were not different due to drinking water from different sources of Mysore city, India [44].

\subsection{Analytical Factors}

Various analytical techniques of AAS, ICP-MS, ASV, XRF, PIXE, NAA, etc., have been used for tooth element analysis after sampling and preparation through acid digestion. Many of the factors influencing trace element levels can be minimized by adopting correct and uniform sampling procedure and appropriate controls. One of the important conditions for ensuring the realistic evaluation of population exposure is the examination of sufficiently large population groups and use of certified reference materials for quality assurance [48].

Several factors affect tooth levels of elements and at the same time in certain cases, both positive and negative influences as well as limited numbers of factors have so far been pointed out. Even then, a detailed consideration of maximum number of the influencing factors will improve quality of analysis and make relevant for comparison within the studies.

\section{Evaluation and Validation of Tooth Element Analysis}

\subsection{Merits}

- There are many advantages which make teeth as an attractive bio-analytical 
material: easy to sample, to preserve and to store without the risk of any change in composition. Tooth composition changes more slowly than soft tissues in response to these factors due to a homeostatic mechanism which prevents either depletion or excess.

- The potential for using lead in whole deciduous teeth, enamel or dentin as an indicator of past exposure of children to lead have been well recommended in many studies [39].

- The tooth levels of lead could be considered as a proxy for skeletal lead which could be analyzed with more difficulties than tooth element analysis [39].

- The advantage of deciduous tooth lead over blood lead analysis lies in the incorporation of lead into the tooth during several years from uterus to exfoliation, compared with blood that has recent exposure [49] [50]. Therefore, element distribution in deciduous teeth may provide retrospective exposure information during fetal development and early childhood.

- Measurement of lead in deciduous teeth seems to be an index of exposure during the peak years of lead ingestion even after blood lead has returned to lower levels [10].

- Milk teeth could be used to investigate the passive exposure from transfer of plutonium from the mother's blood plasma to the fetus, since enamel is formed during pregnancy [51].

- Temporary teeth are free from restorations and hence they are free from one source of external contamination and preferable to permanent teeth which are filled with materials.

- Since there is minimal turnover of lead during tooth life, the level can be related to the quantity of ingested lead [52].

- Lead content of teeth is considerably greater than that of bone, since bone lead loss is related to resorption and change in the bone level, while tooth lead level is permanent [53].

- Lead measurements of archaeological skeletal tissues have shown that enamel is a unique tissue in the body in preserving a reliable record of childhood $\mathrm{Pb}$ exposure long after death and burial [54], since a) it does not undergo post-mortem diagenic contamination, while other skeletal tissues are contaminated from the burial environment [54] excavated tooth samples of preindustrial period are easy to collect in the field and uncomplicated techniques of sample preparation [55].

- Uptake of trace levels of $\mathrm{Cd}, \mathrm{Zn}, \mathrm{Pb}$ and $\mathrm{Cu}$ during formation of the deciduous tooth could be known.

- Serum zinc is a reasonable indicator of the current status. On the other hand, deciduous teeth have been suggested as indicators of long-term, cumulative zinc absorption in early life [37], since the mineralized tooth tissues are relatively stable and retain most of the metal deposited during tooth formation.

- Deciduous teeth showed significantly high lead levels compared to blood; they reflect cumulative exposure and prove to be better indicators of body burden and for predicting neurotoxicity of lead [12]. 
- For legal considerations, analysis of teeth provides a viable alternative to bone for the study of geographical variations in bone-seeking radionuclide contamination [56].

- There is an interest to analyze the chemical composition of enamel from patients with different developmental disorders or syndromes and evaluate possible differences compared to normal composition.

- Past research has relied mostly on fluoride in hair, fingernails or toenails, urine, saliva, blood, bone and enamel as a biomarker of exposure [57]. Among them, urine, saliva, plasma, hair and fingernails are considered as fluoride markers reflecting periods of hours to months. Bone is the best marker for periods of a few years, but it is regularly remodeled, more quickly in children than adults, and also invasive and unsuitable for epidemiological studies. Thus, there is no choice of a useful, relatively long-term marker for fluoride uptake, especially in children, except the primary teeth.

- Fluoride concentration of dentin has been suggested as a biomarker for cumulative exposures [58], since dentin is a promising candidate because similar to bone, it continues to form throughout life but does not normally undergo physiological resorption. Unlike enamel, it is not affected by topical fluoride exposures.

- Incremental growth structures in enamel may provide a basis for interpreting the chronology of dietary transitions during infancy and childhood [59].

- Enamel biopsy by removal of a layer of enamel by acid etching on a limited surface area of tooth, an easy sampling, facilitates wider adoption [29] [49], [60].

\subsection{Demerits}

- A number of problems arise in the analysis of inorganic elements of dental tissues in small, well-defined morphological areas [61] and for wide screening for environmental contamination.

- Examination of elements could not be practiced as a routine form of screening and also not from specific subjects [10], because extraction of healthy permanent teeth just for this purpose is hardly acceptable.

- It is not always easy to collect exfoliated teeth from a population, besides the fact that the collection of deciduous teeth by itself will not provide the researcher with important information regarding the past history of the child, which is more easily collected when the child is examined and a questionnaire is filled by the parents.

- Another drawback of studies on exfoliated teeth is the frequent use of many different teeth from many different regions, which makes comparisons difficult.

- The hardness of enamel and the isolating properties of the hard tissues make the use of various probe techniques difficult. Further, many of elements have such low concentrations that few methods are appropriate for analysis.

- Deciduous teeth, however, are not a uniform mass of calcified tissues. De- 
spite the fact that most studies have dealt with whole tooth element content so far, teeth are anatomically complex being composed of different calcified tissues that harbor different concentrations of elements according to their own developmental characteristics [60].

Taking into consideration of the above two aspects, advantages are more and multifarious, while the limitations are technical and could be minimized following standardized techniques with quality assurance, except the inability of specific, immediate sampling.

\section{Conclusions}

In this presentation, it is concluded that generally, the baseline levels are to be reported in a specific sample groups whose values are compared with random sample groups of other population studies. In such case, standardized analytical methods must be the common condition to avoid much deviation and to identify the influence of factors [62]. Further studies are required for baseline data of other elements of interest, element speciation, relative element levels between tooth and other body organs, ratio between element levels of tooth and whole body store of element.

Both deficiency of essential elements and excess of non-essential and pollutant elements could be assessed in the teeth, even at nanogram level with highly sensitive analytical techniques. Besides single element like lead, fluoride, or radioactive elements, several elements are at a time determined; rare cases of elements of poisoning, fossil hominid and endemic region could be assessed in teeth for forensic and historical importance. Though health problems of major elements are investigated less, trace elements have been observed in relation to deficiency or excess level, since there are possibilities of decreasing or increasing trends of narrow ranges of trace elements due to exposure gradients. Hence, primary concern of trace element status and health implication could be resolved with tooth element analysis. Poor health implication with 1) deficiency or excess of elements, 2) route and sources and 3) biomarkers of element effects, the triangular prediction criteria, are to be further explored for a number of elements.

Several factors influence element levels and considering the factors before sample selection is preferable to considering after sampling. Besides the influencing factors, relative element levels in teeth are to be considered, when heavy metals can replace calcium in hydroxyapatite crystals and evaluation of cadmium and lead levels in tooth should be based not only on the absolute content of these metals but also on the ratio of these metals to calcium [63]. Such ratios are more representative of the relative changes in the levels of accumulated metals and due to interaction resulting in additive and antagonistic effects of elements.

Either deciduous or permanent teeth, is employed alternatively. Among the four parts (enamel, dentin, pulp and cementum), any one or two, are selected for studies. When teeth are of four types (incisor canine, premolar and molar) and location of them are also four (upper, lower, left and right regions), sample type 
availability is mostly random; in such case the choice of selection of their type is to reduce much variation and preferable to any one type, but further studies are required to compare and contrast distribution pattern of elements in all the four parts and types, to identify other factors known to affect tooth elements and to recognize the relationship among element level of body store, exposure sources and functional aspects for prediction of health implication.

\section{Acknowledgements}

The author thanks sincerely The Principal, RIE, Mysore and The Director, NCERT, New Delhi for moral support.

\section{References}

[1] Iyengar, G.V. (1987) Reference Values for the Concentrations of As, Cd, Co, Cr, Cu, $\mathrm{Fe}, \mathrm{I}, \mathrm{Hg}, \mathrm{Mn}, \mathrm{Mo}, \mathrm{Ni}, \mathrm{Pb}, \mathrm{Se}$, and $\mathrm{Zn}$ in Selected Human Tissues and Body Fluids. Biol Trace Elem Res, 12, 263-295. https://doi.org/10.1007/BF02796686

[2] Arruda-Neto, J.D., de Oliveira, M.C., Sarkis, J.E., Bordini, P., Manso-Guevara, M.V., Garcia, F., et al. (2009) Study of Environmental Burden of Lead in Children Using Teeth as Bioindicator. Environ Int, 35, 614-618. https://doi.org/10.1016/j.envint.2008.12.005

[3] Cikrt, M., Smerhovsky, Z., Blaha, K., Nerudova, J., Sediva, V., Fornuskova. H., et al. (1997) Biological Monitoring of Child Lead Exposure in the Czech Republic. Environ Health Perspect, 105, 406-411. https://doi.org/10.1289/ehp.97105406

[4] Karahalil, B., Aykanat, B. and Ertaş, N. (2007) Dental Lead Levels in Children from Two Different Urban and Suburban Areas of Turkey. Int J Hyg Environ Health, 210, 107-112. https://doi.org/10.1016/j.ijheh.2006.08.009

[5] Barton, H.J. (2011) Advantages of the Use of Deciduous Teeth, Hair, and Blood Analysis for Lead and Cadmium Bio-Monitoring in Children. A Study of 6-Year-Old Children from Krakow (Poland). Biol Trace Elem Res, 143, 637-658. https://doi.org/10.1007/s12011-010-8896-6

[6] Burguera, E., Romero, Z., Burguera, M., Burguera, J.L., de Arenas, H., Rondon, C. and di Bernado, M.L. (2002) Determination of Some Cationic Species in Temporary Teeth. J Trace Elem Med Biol, 16, 103-112. https://doi.org/10.1016/S0946-672X(02)80036-0

[7] Karakaya, A., Ilko, M., Ulusu, T., Akal, N., Işimer, A. and Karakaya, A.E. (1996) Lead Levels in Deciduous Teeth of Children from Urban and Suburban Regions in Ankara (Turkey). Bull Environ Contam Toxicol, 56, 16-20.

https://doi.org/10.1007/s001289900003

[8] Rahman, A. and Yousuf, F.A. (2002) Lead LEVELS in Primary Teeth of Children in Karachi. Ann Trop Paediatr, 22, 79-83. https://doi.org/10.1179/027249302125000201

[9] Alomary, A., Al-Momani, I.F., Obeidat, S.M. and Massadeh, A.M. (2013) Levels of Lead, Cadmium, Copper, Iron, and Zinc in Deciduous Teeth of Children Living in Irbid, Jordan by ICP-OES: Some Factors Affecting Their Concentrations. Environ Monit Assess, 185, 3283-3295. https://doi.org/10.1007/s10661-012-2790-y

[10] Habercam, J.W., Keil, J.E., Reigart, J.R. and Croft, H.W. (1974) Lead Content of Human Blood, Hair, and Deciduous Teeth: Correlation with Environmental Factors and Growth. J Dent Res, 53, 1160-1163. 
https://doi.org/10.1177/00220345740530051501

[11] Anttila, A. (1986) Proton-Induced X-Ray Emission Analysis of $\mathrm{Zn}, \mathrm{Sr}$ and $\mathrm{Pb}$ in Human Deciduous Tooth Enamel and Its Relationship to Dental Caries Scores. Arch Oral Biol, 31, 723-726. https://doi.org/10.1016/0003-9969(86)90003-8

[12] Hegde, S., Sridhar, M., Bolar, D.R., Bhaskar, S.A. and Sanghavi, M.B. (2010) Relating Tooth- and Blood-Lead Levels in Children Residing Near a Zinc-Lead Smelter in India. Int J Paediatr Dent, 20, 186-192. https://doi.org/10.1111/j.1365-263X.2010.01032.x

[13] Koizumi, A., Azechi, M., Shirasawa, K., Saito, N., Saito, K., Shigehara, N., et al. (2009) Reconstruction of Human Exposure to Heavy Metals Using Synchrotron Radiation Microbeams in Prehistoric and Modern Humans. Environ Health Prev Med, 14, 52-59. https://doi.org/10.1007/s12199-008-0059-4

[14] Al-Qattan, S.I. and Elfawal, M.A. (2010) Significance of Teeth Lead Accumulation in Age Estimation. J Forensic Leg Med, 17, 325-328. https://doi.org/10.1016/j.jflm.2010.05.001

[15] Kamberi, B., Kqiku, L., Hoxha, V. and Dragusha, E. (2011) Lead Concentrations in Teeth from People Living in Kosovo and Austria. Coll Antropol, 35, 79-82.

[16] Derise, N.L. and Ritchey, S.J. (1974) Mineral Composition of Normal Human Enamel and Dentin and the Relation of Composition to Dental Caries. II. Microminerals. J Dent Res, 53, 853-858. https://doi.org/10.1177/00220345740530041601

[17] Steenhout, A. and Pourtois, M. (1981) Lead Accumulation in Teeth as a Function of Age with Different Exposures. British Journal of Industrial Medicine, 38, 297-303. https://doi.org/10.1136/oem.38.3.297

[18] Needleman, H.L., Tuncay, O.C. and Shapiro, IM. (1972) Lead Levels in Deciduous Teeth of Urban and Suburban American Children. Nature, 235, 111-112. https://doi.org/10.1038/235111a0

[19] dela Cruz, G.G., Rozier, R.G. and Bawden, J.W. (2008) Fluoride Concentration in Dentin of Exfoliated Primary Teeth as a Biomarker for Cumulative Fluoride Exposure. Caries Res, 42, 419-428. https://doi.org/10.1159/000159605

[20] Pikuła, A., Kedra, A., Sałaga-Pylak, M., Stadnik, A., Sokołowska, B. and Borzecki, A. (2004) Comparison of Fluorine Level in the Tissues of Healthy Teeth and Teeth with Decay Process. Ann Univ Mariae Curie Sklodowska Med, 59, 317-320.

[21] Lappalainen, R. and Knuuttila, M. (1982) Atomic Absorption Spectrometric Evidence of Relationships between Some Cationic Elements in Human Dentine. Arch Oral Biology, 27, 827-830. https://doi.org/10.1016/0003-9969(82)90037-1

[22] Nixon, G.S. and Smith, H. (1960) Estimation of Arsenic in Teeth by Activation Analysis. J Dent Res, 39, 514-516. https://doi.org/10.1177/00220345600390031201

[23] Little, M.F. and Steadman, L.T. (1966) Chemical and Physical Properties of Altered and Sound Enamel. IV. Trace Element Composition. Arch Oral Biol, 11, 273-278. https://doi.org/10.1016/0003-9969(66)90128-2

[24] Fischer, A., Wiechuła, D. and Przybyła-Misztela, C. (2013) Changes of Concentrations of Elements in Deciduous Teeth with Age. Biol Trace Elem Res, 154, 427-432. https://doi.org/10.1007/s12011-013-9744-2

[25] Byrne, A.R. and Vrbic, V. (1979) The Vanadium Content of Human Dental Enamel and its Relationship to Caries. Journal of Radioanalytical Chem, 54, 77-85. https://doi.org/10.1007/BF02517763

[26] Kubota, J., Lazar, V.A., Losee, F.L. and Curzon, M.E. (1974) Determination of Strontium in Ground and Whole Teeth by X-Ray Emission Spectrography. J Dent 
Res, 53, 1276-1279. https://doi.org/10.1177/00220345740530053301

[27] Retief, D.H., Cleaton-Jones, P.E., Turkstra, J. and De Wet, W.J. (1971) The Quantitative Analysis of Sixteen Elements in Normal Human Enamel and Dentine by Neutron Activation Analysis and High-Resolution Gamma-Spectrometry. Arch Oral Biol, 16, 1257-1267. https://doi.org/10.1016/0003-9969(71)90029-X

[28] Brudevold, F., Reda, A., Aasenden, R. and Bakhos, Y. (1975) Determination of Trace Elements in Surface Enamel of Human Teeth by a New Biopsy Procedure. Arch Oral Biol, 20, 667-673. https://doi.org/10.1016/0003-9969(75)90135-1

[29] Schamschula, R.G., Bunzel, M., Agus, H.M., Adkins, B.L., Barmes, D.E. and Charlton, G. (1978) Plaque Minerals and Caries Experience: Associations and Interrelationships. J Dent Res, 57, 427-432. https://doi.org/10.1177/00220345780570030101

[30] Nixon, G.S. and Helsby, C.A. (1976) The Relationship between Strontium in Water Supplies and Human Tooth Enamel. Arch Oral Biol, 21, 691-695. https://doi.org/10.1016/0003-9969(76)90144-8

[31] Steadman, L.T., Brudevold, F. and Smith, F.A. (1958) Distribution of Strontium in Teeth from Different Geographic Areas. J Am Dent Assoc, 57, 340-344. https://doi.org/10.14219/jada.archive.1958.0161

[32] Nixon, G.S. and Myers, V.B. (1970) Estimation of Selenium in Human Dental Enamel by Nuclear Activation Analysis. Caries Res, 4, 179-187. https://doi.org/10.1159/000259639

[33] Hadjimarkos, D.M. and Bonhorst, C.W. (1959) The Selenium Content of Human Teeth. Oral Surg Oral Med Oral Pathol, 12, 113-116. https://doi.org/10.1016/0030-4220(59)90088-X

[34] Soremark, R. and Samsahl, K. (1962) Analysis of Inorganic Constituents in Dental Calculus by Means of Neutron Activation and Gamma-Ray Spectrometry. J Dent Res, 41, 596-602. https://doi.org/10.1177/00220345620410031101

[35] Brudevold, F. and Steadman, L.T. (1955) A Study of Copper in Human Enamel. $J$ Dent Res, 34, 209-216. https://doi.org/10.1177/00220345550340020701

[36] Fischer, A., Kwapuliński, J., Wiechuła, D., Fischer, T. and Loska, M. (2008) The Occurrence of Copper in Deciduous Teeth of Girls and Boys Living in Upper Silesian Industry Region (Southern Poland). Sci Total Environ, 389, 315-319. https://doi.org/10.1016/j.scitotenv.2007.08.046

[37] Fosse, G. and Justesen, N.P. (1978) Lead in Deciduous Teeth of Norwegian Children. Arch Environ Health, 33, 166-175. https://doi.org/10.1080/00039896.1978.10667329

[38] Nixon, G.S., Livingston, H.D. and Smith, H. (1967) Estimation of Zinc in Human Enamel by Activation Analysis. Arch Oral Biol, 12, 411-416. https://doi.org/10.1016/0003-9969(67)90226-9

[39] Omar, M., Ibrahim, M., Assem, H., Moustafa, Y. and Battah, F. (2001) Teeth and Blood Lead Levels in Egyptian Schoolchildren: Relationship to Health Effects. J Appl Toxicol, 21, 349-352. https://doi.org/10.1002/jat.771

[40] Gil, F., Pérez, M.L., Facio, A., Villanueva, E., Tojo, R. and Gil, A. (1994) Dental Lead Levels in the Galician Population, Spain. Sci Total Environ, 156, 145-150. https://doi.org/10.1016/0048-9697(94)90351-4

[41] Lyngbye, T., Hansen, O.N. and Grandjean, P. (1991) Lead Concentration in Deciduous Teeth from Danish School Children. Dan Med Bull, 38, 89-93.

[42] Costa de Almeida, G.R., de Sousa Guerra, C., de Angelo Souza Leite, G., Antonio, R.C., Barbosa Jr., F., Tanus-Santos, J.E. and Gerlach, R.F. (2011) Lead Contents in 
the Surface Enamel of Primary and Permanent Teeth, Whole Blood, Serum, and Saliva of 6- to 8-Year-Old Children. Sci Total Environ., 409, 1799-1805. https://doi.org/10.1016/j.scitotenv.2011.01.004

[43] Watanabe, K., Tanaka, T., Shigemim, T., Hayashida, Y. and Maki, K. (2009) Mn and $\mathrm{Cu}$ Concentrations in Mixed Saliva of Elementary School Children in Relation to Sex, Age, and Dental Caries. J Trace Elem Med Biol, 23, 93-99. https://doi.org/10.1016/j.jtemb.2009.01.003

[44] Nagaraj, G., Sukumar, A., Nandlal, B., Vellaichamy, S., Thansekaran, K. and Ramanathan, A.L. (2009) Tooth Element Levels Indicating Exposure Profiles in Diabetic and Hypertensive Subjects from Mysore, India. Biol Trace Elem Res, 131, 255-262. https://doi.org/10.1007/s12011-009-8371-4

[45] Alomary, A., Al-Momani, I.F. and Massadeh, A.M. (2006) Lead and Cadmium in Human Teeth from Jordan by Atomic Absorption Spectrometry: Some Factors Influencing Their Concentrations. Sci Total Environ., 369, 69-75. https://doi.org/10.1016/j.scitotenv.2006.04.023

[46] Shashikiran, N.D., Subba Reddy, V.V. and Hiremath, M.C. (2007) Estimation of Trace Elements in Sound and Carious Enamel of Primary and Permanent Teeth by Atomic Absorption Spectrophotometry: An In Vitro Study. Indian J Dent Res, 18, 157-162. https://doi.org/10.4103/0970-9290.35824

[47] Kumagai, A., Fujita, Y., Endo, S. and Itai, K. (2012) Concentrations of Trace Element in Human Dentin by Sex and Age. Forensic Sci Int, 219, 29-32. https://doi.org/10.1016/j.forsciint.2011.11.012

[48] Subramanian, R. and Sukumar, A. (1988) Biological Reference Materials and Analysis of Toxic Elements. Fresenius Z Anal Chem, 332, 623-626. https://doi.org/10.1007/BF00472655

[49] Cleymaet, R., Collys, K., Retief, D.H., Michotte, Y., Slop, D., Taghon, E., et al. (1991) Relation between Lead in Surface Tooth Enamel, Blood, and Saliva from Children Residing in the Vicinity of a Non-Ferrous Metal Plant in Belgium. Br J Ind Med, 48, 702-729. https://doi.org/10.1136/oem.48.10.702

[50] Robbins, N., Zhang, Z.F., Sun, J., Ketterer, M.E., Lalumandier, J.A. and Shulze, R.A. (2010) Childhood Lead Exposure and Uptake in Teeth in the Cleveland Area during the Era of Leaded Gasoline. Sci Total Environ, 408, 4118-4127. https://doi.org/10.1016/j.scitotenv.2010.04.060

[51] Froidevaux, P. and Haldimann, M. (2008) Plutonium from Above-Ground Nuclear Tests in Milk Teeth: Investigation of Placental Transfer in Children Born between 1951 and 1995 in Switzerland. Environ Health Perspect, 116, 1731-1734. https://doi.org/10.1289/ehp.11358

[52] Bloch, P., Shapiro, I.M., Soule, L., Close, A. and Revich, B. (1998) Assessment of Lead Exposure of Children from K-XRF Measurements of Shed Teeth. Appl Radiat Isot, 49, 703-705. https://doi.org/10.1016/S0969-8043(97)00207-8

[53] Frank, R.M., Sargentini-Maier, M.L., Turlot, J.C. and Leroy, M.J. (1990) Comparison of Lead Levels in Human Permanent Teeth from Strasbourg, Mexico City, and rural zones of Alsace. J Dent Res, 69, 90-93. https://doi.org/10.1177/00220345900690011601

[54] Budd, P., Montgomery, J., Cox, A., Krause, P., Barreiro, B. and Thomas, R.G. (1998) The Distribution of Lead within Ancient and Modern Human Teeth: Implications for Long-Term and Historical Exposure Monitoring. Sci Total Environ, 220, 121-136. https://doi.org/10.1016/S0048-9697(98)00244-7

[55] Kuhnlein, H.V. and Calloway, D.H. (1977) Minerals in Human Teeth: Differences 
betwe Preindustrial and Contemporary Hopi Indians. The American Journal of Clinical Nutrition, 30, 883-886. https://doi.org/10.1093/ajcn/30.6.883

[56] O’Donnell, R.G., Mitchell, P.I., Priest, N.D., Strange, L., Fox, A., Henshaw, D.L. and Long, S.C. (1997) Variations in the Concentration of Plutonium, Strontium-90 and Total Alpha-Emitters in Human Teeth Collected within the British Isles. Sci Total Environ, 201, 235-243. https://doi.org/10.1016/S0048-9697(97)84060-0

[57] Nagaraj, G. and Sukumar, A. (2011) Biological Monitoring of Environmental and Occupational Exposure of Human Beings to Trace Elements. J. Ecobiol, 28, 201-210.

[58] Selwitz, R.H. (1994) Strategies for Improving Methods of Assessing Fluoride Accumulation in Body Fluids and Tissues. Adv Dent Res, 8, 111-112. https://doi.org/10.1177/08959374940080010301

[59] Humphrey, L.T., Dean, M.C., Jeffries, T.E. and Penn, M. (2008) Unlocking Evidence of Early Diet from Tooth Enamel. Proc Natl Acad Sci U S A, 105, 6834-6839. https://doi.org/10.1073/pnas.0711513105

[60] Purchase, N.G. and Fergusson, J.E. (1986) Lead in Teeth: the Influence of the Tooth Type and the Sample within a Tooth on Lead Levels. Sci Total Environ, 52, 239-250. https://doi.org/10.1016/0048-9697(86)90124-5

[61] Jälevik, B., Odelius, H., Dietz, W. and Norén, J. (2001) Secondary Ion Mass Spectrometry and X-Ray Microanalysis of Hypomineralized Enamel in Human Permanent First Molars. Arch Oral Biol., 46, 239-247. https://doi.org/10.1016/S0003-9969(00)00113-8

[62] Sukumar, A. and Subramanian, R. (1999) Characterization of Human Teeth for Trace Elements. Proceedings of the Second National Workshop on Development and Use of Reference Materials. LATS/15/2000. Central Pollution Control Board, Delhi, 86-88.

[63] Tvinnereim, H.M., Fantaye, W., Isrenn, R., Bjorvatn, K., Melaku, Z. and Teklehaimanot, R. (2011) Lead Levels in Primary Teeth in Children from Urban and Rural Areas in Ethiopia. Ethiop Med J., 49, 61-66. 